\title{
GRAMMAR AS COMMUNICATION: A DISCOURSE GRAMMAR OF DEIXIS
}

Drissia Chouit $\varangle$; Research Laboratory LaRCIGALS, Moulay Ismail University of Meknes, Morocco

\begin{abstract}
This research article examines the micro -system THIS/THAT in contemporary English within the theoretical fr amework of Metaoperational Grammar. It proposes a new approach to bring into light how this pair functions, giving due account to the importance of $t$ he context and the communication goals that determine the selection of one of these operators in a given communication act. It aims, therefore, to bridge the gap between "grammar" and "communication" and to show that grammatical operators are at the heart of communication strategies and semantic interpretation. These insights into the functioning of THIS and TH AT present, in fact, one of my main contributions to modern linguistics. Metaoperational Grammar has provided me with theoretical tools to (1) show the limitations of descriptive approaches which base their explanation of this pair on the proximal/non -proximal distinction; (2) bring into light the abstract mechanisms underlying the processing of these operators; and (3) show the role played by grammati cal operators in building semantic interpretation and revealing the communication strategies of the speaker. Based on authentic examples, this article shows that the spatial -temporal parameters of proximity to the speaker (THIS) and distance from the speak er (THAT) are not endowed with explanatory power to account for the emergence of these operators in discour se, and hence the need for a discourse grammar of deixis.
\end{abstract}

Keywords: Deictics THIS/THAT; Discourse Grammar; Metaoperational Grammar; Semantics of Grammar; Processing of Utterances; Communication Strategies.

d.chouit@umi.ac.ma

Citation: Chouit. D. (2021). Grammar as communication: A discourse grammar of deixis . Social Sciences, Humanities and Education Journa $\quad$ l(SHE Journal) ， 2(2), $96 \quad$ - 111. DOI: $10.25273 /$ she.v2i2.9229

\section{(cc) BY-Ne-SA}

Published by Universitas PGRI Madiun. This work is licensed under the Creative Commons Attribution-NonCommercialShareAlike 4.0 International License. 


\section{INTRODUCTION}

The term deixis is used in linguistics to show the link between language use and referents in the spatialtemporal context of communication. The main types of deixis are person, time and place which encode reference to the personal, temporal and spatial characteristics anchored to the situation of communication. This article will be devoted to deictics THIS/THESE and THAT/THOSE, known in the tradition as demonstrative pronouns/adjectives.

This study aims to show the limitations of the proximal/non-proximal distinction, as it cannot explain the abstract mechanisms underlying the processing of THIS/THESE and THAT/THOSE. Its main purpose is, therefore, to explain what happens in the process of utterance construction, and how grammatical forms reflect the speaker's communication strategies, and play an important part in building semantic interpretation. THIS and THAT will be analysed in various contexts in order to show their respective grammatical invariants -the abstract grammatical property that underlies all the occurrences of each one of them- and how they are invested by speakers in various communication contexts. All examples used to support the analysis are authentic, taken from natural contexts that show these grammatical operators in use.

This study is undertaken within the framework of Metaoperational Grammar which revolves around the discovery that grammatical operators such as THIS and THAT are tangible discursive traces of the abstract operations underpinning the processing of utterances. The term "abstract" is of extreme importance in this theory as we need to attain a certain level of abstraction, through adequate theoretical tools, in order to be able to account for the abstraction of grammatical operations. This study provides the opportunity to show the importance of this approach to language, as we cannot have a proper understanding of how language works if we simply attach to language structures the various meanings pertaining to the extralinguistic world such as proximity to or distance from the speaker.

This research article starts with a brief presentation of Metaoperational Grammar. Part two examines THIS, identifying its invariant and showing the role it plays in encoding the speaker's communication strategies and building semantic interpretation. Part three explores THAT in contrast to THIS, showing the differences between these two operators in the process of discourse building, the relationship between the speaker and the addressee, and the part they play in constructing the meaning of utterances. Finally, part four addresses the important issue of how to opt for either THIS or THAT in particular contexts and explains the difference in meaning and communication strategies for contexts that allow both THIS and THAT.

\section{Metaoperational Grammar}

Metaoperational

Grammar considers exploring grammar in context a condition to get insights into the inner organisation of languages. In fact, this theoretical framework has shown that grammatical operators like THIS and THAT are visible discursive traces of the invisible operations underlying the processing of utterances, in the sense that when we communicate, we do not transmit messages only, but also the way they have been processed from mind to discourse. If these abstract operations underpinning the construction of utterances are invisible to the naked eye, it is the task of linguists to forge theoretical tools that target this invisible phase of passage from language -as a conception in the mind- to utterances. Metaoperational Grammar was invented 
to this effect: using grammatical operators to decipher what happens in the process of utterance construction. This is known as the Theory of the Processing of Utterances.

Other major concepts of Metaoperational Grammar include the Theory of the Invariance and the Theory of Phases. Identifying invariants is of extreme importance as Metaoperational Grammar relates the adequacy of a linguistic theory to its capacity to account for all occurrences of a particular grammatical operator in context; no room is, then, left to exceptions. As to the Theory of Phases, which is the fundamental axis of Metaoperational Grammar, it maintains that languages are organised in binary systems based on the contrast between two phases in the processing of utterances: phase 1 corresponds to open choice when the speaker is at the stage of selecting elements from an open paradigm to give form to the message he/she wants to transmit; and phase 2 corresponds to the post-selection stage referring to a closed paradigm, when the speaker relies on what has been already stated or known. This two-phase distinction is reflected in various micro-systems of English like THIS/THAT, A/THE, NEARLY/ALMOST, etc. The analysis of THIS and THAT in this article will show these concepts at work. We will use the open paradigm/closed paradigm distinction to show how this pair works, giving evidence that THIS corresponds to an open paradigm, and THAT corresponds to a closed paradigm.

\section{THIS}

\section{Open Paradigm}

To us, THIS is an abstract operator, the main function of which is to indicate that the noun or noun phrase to which it applies has been selected from an open paradigm of possibilities:
1) "Now that his rage was gone he was excited by this storm as he was by all storms. In a blizzard, a gale, a sudden line squall, a tropical storm, or a summer thunder shower in the mountains there was an excitement that came to him from no other thing." (E. Hemingway: For Whom the Bell Tolls, p.176)

2) "I urge all Federal agencies, interested organizations, groups and individuals to fly the flag of the United States at half-staff this December 7 in honour of those who died as a result of their service at Pearl Harbour." (A Proclamation by the President of the United States of America on the National Pearl Harbour Remembrance Day, December 4, 2007)

Example (1) makes explicit the abstract mechanism underlying the emergence of THIS in discourse. The author perceives THIS STORM as one element in a list of storms that are source of immense excitement to him. He even enumerates the elements of this list, from which THIS STORM has been selected. This choice from an open list of possibilities entails, in fact, the comparison between elements of the list. The comparison with other elements is particularly clear in example (2). THIS DECEMBER 7 is perceived in comparison to other days of the calendar year: concerned authorities are asked to fly the flag of the United States at half-staff on this day commemorating the National Pearl Harbour Remembrance Day, as compared to other days and other national celebrations. The following examples confirm this analysis:

3) "[The Statue of Liberty] has been an inspiration to generations of immigrants. One of these immigrants was a poet-writer named Ameen Rihani." (President Bush Discussing Importance of Freedom in the Middle East, January 13, 2008, United Arab Emirates: www.whitehouse.gov) 
4) "This is not the first time Pope Benedict has been at the centre of criticism for his views on Islam." ( $B B C$ News, September 15, 2006)

In example (3), reference to one element of the list is very clear: ONE OF THESE IMMIGRANTS. As to example (4), it is taken from an article written at a time of big controversy created over the declaration of Pope Benedict XVI on Islam, at Regensburg University, Germany. The BBC religious affairs correspondent traced back views on Islam expressed by Pope Benedict when he was a cardinal to show that what he said this time was not an isolated incidence, but one in a number of declarations on Islam which caused big turmoil. This explains why the journalist used THIS: "This is not the first time...."

So far, it is clear that the fundamental grammatical property underpinning THIS lies in the selection of one item from an open paradigm. It follows that the selected element is perceived by the speaker in comparison to other elements, other ways, other definitions, other visions of the world. The attitude of the speaker is of prime importance in the Metaoperational approach, as it is through the speaker's eyes that we get access to the representation of the world. THIS presents to us the speaker's vision of the world, and how he/she constructs reality:

5) "The principle of inoculation can be explained with the biological analogy on which it is based. Suppose that you lived in a germ-free environment. Upon leaving this germ-free environment and upon exposure to germs, you would be particularly susceptible to infection because your body has not built up immunity -it would have no resistance. Resistance, (...), might be achieved by the body; if not naturally, then through some form of inoculation. (...).
The situation in persuasion is similar to this biological process." (Joseph A. Devito: The Elements of Public Speaking, p.345)

6) 'Ay,' he said aloud. There is no translation for this word and perhaps it is just a noise such as a man might make, involuntarily, feeling the nail go through his hands and into the wood." (E. Hemingway: The Old Man and the Sea, p.92)

The abstract mechanisms underpinning the processing of THIS are well evidenced in these examples. In example (5) the author is imagining a situation that has no direct reference to the outside world. His use of THIS reveals his attitude vis-à-vis what he structures: He does not present what he structures as exclusive, but THIS GERMFREE ENVIRONMENT is perceived in contrast to the common environment where people are normally exposed to germs. It is this comparison which will help the author to introduce the concept of "inoculation" to his readers, hence the importance of the fundamental abstract property of THIS which we have brought into light. In fact, THIS shows that the speaker is in the phase of selection of elements in order to give form to his ideas. Example (6) is particularly revealing in this regard: the author named "AY" a word (THIS WORD), and then he thought it over and reconsidered this definition, stating that it is perhaps "just a noise." This attitude of the speaker vis-à-vis what he structures has implications on his relationship with the addressee (or audience).

\section{THIS and the Relationship Speaker/Addressee}

In fact, since the speaker is in the phase of selection of items from a list of possibilities, the addressee is not supposed to share what he/she will talk about. The goal of communication is, 
therefore, to inform the addressee/audience on how he/she perceives a particular issue. Therefore, opting for THIS in a particular context corresponds to a communication strategy based on two inter-related concepts: (1) selection of an element from an open paradigm, and (2) noninvolvement of the addressee as the latter waits for the speaker to unfold a piece of information and share it with him/her. Even when THIS is anaphoric to the previous context as in examples (5) and (6), the choice remains open as the speaker refers to what has been said before in order to complete it, amend it, specify the meaning of some terms, clarify one angle, etc, as it is clear in the following examples:

7) "Thousands of Gazans are pouring into Egypt for a fourth day. This Gaza crisis began nine days ago, when Israel cut off the seaside territory, denying it supplies." (BBC News, January 26, 2008)

8) "Indeed she advocated that a good teacher should go in for "creative subversion." By this, she meant that teachers should neither passively comply with government initiatives, nor should they point blank refuse to implement them." (BBC News, January 26, 2008)

9) "Citing studies that showed the academic gains from children working collaboratively in groups, she argued: "If learners are not involved in their learning, they do not learn."

She noted that teachers liked to be given practical guidance on how to improve their teaching, yet what they really needed to develop was their own judgment of what works and what does not work with their own teaching.

This emphasis on engaging pupils and self-reflecting teaching might horrify those who support a more traditional subject-based,

discipline-oriented approach." (ibid)

In example (7), the journalist uses THIS to talk about the 2008 Gaza crisis, as this is not the first time that the Gaza Strip has been the scene of a big crisis. The purpose behind this communication strategy is to introduce background information concerning this event. In example (8), the journalist uses THIS to explain the meaning of the quoted material "creative subversion" which might be difficult to some readers. And in example (9), the same journalist uses THIS to summarize the preceding paragraphs in a noun phrase "this emphasis on engaging pupils and selfreflecting teaching" in order to contrast it with the other point of view: "those who support a more traditional subject-based, discipline-oriented approach."

This explanation shows that whatever is conveyed through THIS is open to debate, reconsideration, rethinking as it is one perspective among others. This abstract invariant governing all occurrences of THIS has helped me make a breakthrough in modern linguistics concerning one of the thorniest issues relating to THIS: Is it possible to express a point of view using THIS? And what is the status of this judgment?

\section{THIS and Assertion}

Most grammars and linguistic research maintain that when a speaker wants to express a point of view, he/she chooses THAT, not THIS as the latter is presumed to present the judgment as an inherent characteristic of the item in question. I devoted one of the main parts of my doctoral dissertation to show that this presumption, though largely propagated, is not based on solid grounds. To me, THIS is the grammatical tool used, by excellence, to structure a personal point of view, as it is shown in the following examples: 
10) "Reporters who rushed to the death scene, (...), were roughed up, and the film was ripped from photographers' cameras." Catch these bastards," an officer commanded. "Make sure not one of them flees. Snatch their cameras." (Time, September 30, 1996, p.26)

11) "The tone of the Obama-Clinton race has pundits worried." The concern in this bitter campaign could end up hurting whoever the nominee is, "CNN's Jack Cafferty warned last week. The contest, Peggy Noonan wrote in the Wall Street Journal, is "tearing the party apart." On MSNBC, Newsweek's Howard Fineman dubbed it a "civil war." (The Washington Post, January 31, 2008, p. A.21)

12) "Pope Benedict XVI has cancelled a visit to a prestigious university in Rome where lecturers and students have protested against his views on Galileo. (...)

The academics at La Sapienza signed a letter saying Pope Benedict's views on Galileo "offend and humiliate us."

They said it would be inappropriate for the Pope to open their academic year on Thursday.

"In the name of the secular nature of science we hope this incongruous event can be cancelled," said the letter addressed to the university's rector." (BBC News, January 15, 2008)

The stand of the speaker, based on the way he/she sees the world, is clear in these examples. In example (10), it is the officer who considers journalists as "bastards," using THESE. He is the only responsible for such value judgment, which represents his own perception as opposed to other views. This semantic interpretation making of THIS the operator used to express the views and attitudes of the speaker emanates from the abstract mechanism underlying all occurrences of THIS, which is the selection of an item from an open paradigm. The abstract invariant of THIS sheds light on another important dimension of this operator. In fact, THIS is used in cases of ASSERTION. When the speaker wants to assert strongly what he/she says, he/she opts for THIS. This assertive value comes from the possibility of confrontation with other views, as issues are open-ended, and the door is not closed to debate. This is why when an issue is examined from multiple viewpoints, THIS is used to express one view compared to other possible stands.

In example (11), the columnist presents how the Obama-Clinton race to the White House is interpreted by experts in various mass media. THIS BITTER CAMPAIGN conveys CNN's view as compared to other views: the Wall Street Journal and MSNBC. In example (12), it is the view of the academics at La Sapienza University which is expressed through THIS INCONGRUOUS EVENT: they consider the scheduled visit of Pope Benedict XVI to their university as an "incongruous event." This view is not shared by the Vatican; otherwise, the visit would not have been scheduled. But, the Vatican, while defending the Pope, decided to cancel his visit because of the firm stand of scholars. The assertive value inherent to THIS is very clear in this example as the voice opposing the Papal visit sticks to its position and defends it strongly, maintaining that this visit should not take place. The clash between the two positions is so strong that one of them is forced to withdraw, hence the decision taken by the Vatican to cancel the Pope's visit to that university.

These examples show the abstract mechanism underpinning THIS at work as well as the important role played by grammatical operators in building semantic interpretation. Here are other examples which consolidate this analysis: 
13) "What that prosecutor did, hiding evidence while at the same time actively pursuing the death penalty for me, could be seen as an attempted murder. When I found out that he had covered up so much evidence and was still alleging that I got away with murder, even after I was released, I started talking to attorneys. I figured that this monster was never going to let me live, not as a free and innocent person anyway. I took out a lawsuit against him." (The Guardian Weekly, November 23, 2007)

14) "Another eternity in this flying coffin." (Tintin: The Red Sea Sharks)

Example (13) is taken from a news story describing the fight of Ray Krone who was sentenced to death for a murder he did not commit. He was freed after spending ten years in an Arizona Prison. According to the story he recounted, the main problem during his detention at the death row and even after his release was the prosecutor. He was the source of all his misfortunes; this is why he considers him to be a "monster". Drawing on his personal experience with that man, he uses THIS to say that to him he is not a human being, but a "monster." He asserts strongly this stand as he believes firmly that that man would never let him live in peace, hence his decision to sue him. The firm assertion transmitted via THIS shows, once again, the importance of linguistic analysis based on understanding what happens in the process of utterance construction. We are in presence of abstract relations that represent views and conceptions, reflecting how the speaker, the architect of discourse, experiences events.

Example (14) is particularly interesting in this regard, as it exhibits the creative power of natural languages. In fact, the speaker, Captain Haddock, who was travelling by plane, described the aeroplane as a "flying coffin." He opted for THIS to create his own image and to attribute it to the aeroplane in question. It is to be highlighted that the noun phrase "flying coffin" has no equivalent in the real world as it corresponds to nothing concrete. Besides, there is no accepted meaning of "flying coffin," this is why THIS is used to make readers navigate in the imaginary world of the speaker and help them reconstruct the intended message. This example shows not only the assertive value of THIS, but also how grammatical operators may enable the speaker to create his/her own images, to define things from his/her own perspective and experiences and to make sense of the world.

It is to be underlined that both the assertive value of THIS and its use to express the point of view of the speaker, which does not involve the addressee, stem from the abstract invariant depicted and illustrated in this analysis, which is the selection of an item from a list of possibilities. THAT, on the other hand, refers to a closed paradigm, as it will be shown below.

\section{THAT}

\section{Closed Paradigm}

Contrary to THIS, THAT refers exclusively to one element, possibility or vision:

15) "Another source close to the Kennedy family says Senator Kennedy was upset about two instances that occurred on a single day of campaigning in New Hampshire on January 7, a day before the state's primary. (...)

Both comments that day, by Clinton and her supporter, were meant to make the point that Clinton would be better equipped to get things done as president than Obama." (The Washington Post, January 30, 2008)

16) "Arab rulers, regardless of their differences, agree on one thing, and that is the way they regard the Arab press." 
(Press Under Siege: Media in Danger Conference, Beirut, 10-11 December, 2006)

In example (15), THAT DAY refers to one "single day on January 7, 2008," and what happened on that particular day, excluding any other day. Similarly, in example (16) the speaker tackles one exclusive issue, "THAT is the way Arab rulers regard the Arab press," referring to the one conception that all of them share. These examples show the difference between THIS and THAT, in the sense that THAT operates within a closed paradigm: reference is made exclusively to one element in itself and by itself. Of course, that element must be previously known, and that information shared by both the speaker and the addressee. This has implications on the relationship between the two parties involved in a communication act. Prior to the emergence of THAT, the addressee (or audience) is supposed to know what THAT refers to, either by referring to the previous context, the situation of communication or shared knowledge.

\section{THAT and the Relationship Speaker/Addressee}

The addressee is always involved in what is structured by THAT, as he/she is expected to share the same information or stands expressed by the speaker. The involvement of the interlocutor comes from the fact that there is no choice with THAT. When building on the previous context, the speaker addresses only elements mentioned in that context on their own, with no possibility to indulge into comparisons with other elements. Therefore, the closed paradigm and involvement of the addressee are intertwined; they constitute the fundamental grammatical property underlying all the occurrences of THAT. Consider the following examples:
17) "All my life, people have told me that my father changed their lives, that they got involved in public service or politics because he asked them to. And the generation he inspired has passed that spirit on to its children. I meet young people who were born long after John F. Kennedy was president, yet who ask me how to live out his ideals.

Sometimes it takes a while to recognize that someone has a special ability to get us to believe in ourselves, to tie that belief to our highest ideals and imagine that together we can do great things. In those rare moments, when such a person comes along, we need to put aside our plans and reach for what we know is possible.

We Americans have that kind of opportunity with Senator Obama. It isn't that the other candidates are not experienced or knowledgeable. But this year, that may not be enough. We need a change in the leadership of the United States -just as we did in 1960. (...)

I have never had a president who inspired me the way people tell me my father inspired them. But for the first time, I believe I have found the man who could be that president, not just for me, but for a new generation of Americans." (International Herald Tribune, January 28, 2008)

18) "'We, too, want a president who appeals to the hopes of those who still believe in the American dream and those around the world who still believe in the American ideal and who can lift our spirits and make us believe again,' Kennedy said, in announcing his choice at a raucous, highly charged rally at American University in Washington. 'I have found that candidate and I think you have, too.'

He praised Clinton and the third Democratic candidate, John Edwards, but 
said one candidate, Obama, had risen above the rest." (International Herald Tribune, January 28, 2008)

We notice how grammatical forms are used in the persuasive speech of both Caroline Kennedy (example 17) and Senator Edward Kennedy (example 18). Both invest the abstract invariant of THAT as an operator which targets one exclusive element, idea or vision, endorsed both by the speaker and the audience, to foster the idea of the uniqueness of candidate Obama in the mind of the audience, and to present him as the only one capable of making the change that Americans have been longing for.

In example (17), we notice a condensed use of THAT. In this article entitled "A President like my father," Caroline Kennedy started talking about her father John F. Kennedy and how he managed to get people of his nation involved in public service and politics. She used THAT to underline that THAT SPIRIT was particular to her father only, and to no one else. THAT SPIRIT which mobilized people and stimulated their interests in public affairs has been transmitted from the generation directly inspired by that president to the younger generation. This is why this new generation has to seize the candidature of Senator Obama as the unique opportunity (THAT KIND OF OPPORTUNITY) for Americans to make a significant shift in the leadership of the United States. To this effect, she draws a comparison between President John F. Kennedy and Senator Obama, as she says that Obama evokes the same elevated feelings that people used to feel when J.F. Kennedy was president. She makes it clear that her stand is not limited to her own view that presents her own perception of American politics, but embraces the view of a whole new generation that was described at the beginning of the article as being inspired by her father's ideals. This is stated explicitly in the closing words of her article: "I believe I have found the man who could be that president -not just for me, but for a new generation of Americans." This is a clear appeal for Americans longing for change in the American leadership to vote for her preferred candidate. She draws on the nation's shared knowledge about a highly-praised figure in the contemporary history of the United States to design brilliant prospects for America, if led by the unique candidate (THAT PRESIDENT) who can transform this dream into reality. Likewise, when Senator Edward Kennedy proclaimed his choice for Obama, he presented him as the only candidate with the potential to realize the American dream: "one candidate, Obama, had risen above the rest." THAT has enabled him to transmit a shared position between him -as speaker- and the audience: "I've found that candidate and I think you have, too."

This abstract mechanism underlying the processing of THAT applies to the expression of views using this operator. Contrary to THIS which is used to express the point of view of the speaker and how he/she perceives the world, THAT is used to express a shared stand by the speaker and the addressee or audience, an unarguable position as it voices an attitude agreed upon by the concerned parties in a communication act:

19) "Mozart, that great composer, died in 1791." (H. Adamczewski and J-P. Gabilan: Déchiffrer la grammaire anglaise, p.227)

20) "On National Pearl Harbor Remembrance Day, America honors those brave individuals who made the ultimate sacrifice in defense of our homeland, and we recognize those veterans who with strength and resolve defended our Nation and advanced the cause of freedom during World War II. 
When it mattered most, an entire generation of Americans stepped forward to protect our freedom and to defend liberty. Their devotion to duty and willingness to serve a cause greater than self helped secure our future and our way of life. Liberty prevailed because of the sacrifice of these courageous patriots, and America and her allies preserved a world where democracy could flourish. Our Nation remains forever in the debt of these brave Americans.

From the unprovoked attack at Pearl Harbor grew a steadfast resolve that has made America a defender of freedom around the world, and our mission continues as our men and women in uniform serve at home and in distant lands. Today, as we defend our Nation's founding ideals, we pay special tribute to those who lost their lives at Pearl Harbor, honor our veterans of World War II, and celebrate the liberty that makes America a lasting symbol of hope to the world.

(A Proclamation by the President of the United States of America on National Pearl Harbor Remembrance Day, December 4, 2007)

It is clear in these examples that when the speaker uses THAT/THOSE, he/she structures an exclusive view, closed to debate as it is shared by the speaker and the audience. No one would argue about Mozart being a "great composer." Similarly, when the Former President of the United States George W. Bush addressed the nation on the occasion of the commemoration of the Pearl Harbour Remembrance Day, he put forward the voice of a whole nation, expressing its gratitude to those who sacrificed their lives in defence of the country. Contrary to THIS, THAT has no assertive value, as there is no need to assert evidence, something already endorsed by the receiver of the message, who shares the same view as the speaker. Yet, in example (20), we see that George W. Bush used THOSE to express the common vision with the audience, and then he used THESE to refer to the same individuals, but from another perspective. In line with my analysis, when Bush said THESE COURAGEOUS PATRIOTS and THESE BRAVE AMERICANS, he wanted to highlight his position as head of the American nation: it is known that those veterans were "courageous patriots" and "brave Americans," but he, as president, wanted to assert this fact to emphasize its prominence. Note also that he used the words "patriots" and "Americans" to place these individuals within the whole American "tapestry," in order to highlight the idea that America is a multi-fold presentation of "courageous patriots" and "brave Americans." We see then how the fundamental property of open paradigm underlies all occurrences of THIS/THESE. Then, he used THOSE "those who lost their lives at Pearl Harbor" to close his speech, highlighting the unified vision of the American nation paying tribute to its veterans. This speech is edifying as it shows that nothing in language is constructed at random, but is the result of CALCULATIONS on the part of the speaker, depending on the context and the intention of communication. Grammatical operators like THIS and THAT are of extreme importance in this regard as they are the key to help receivers decipher these calculations and reconstruct the intended message. This explains the importance of a linguistic grammar of English: a grammar based on linguistic research, a grammar that makes language intelligible and learners autonomous. Metaoperational Grammar has proved its efficiency in this regard, as it has provided me with adequate theoretical tools to carry out this study and bring into light the abstract mechanisms underlying the processing of these operators. The adequacy of this theoretical framework will be further confirmed when it comes to make the 
appropriate choice between THIS and THAT in particular contexts.

\section{THIS or THAT? That is the question.}

It is true that sometimes we have the possibility to use either THIS or THAT in a particular context, but as I have explained in example (20) above, the meaning is not the same because the communication strategy is fundamentally different. In fact, we are in presence of subtle meanings, difficult to decode if one is not equipped with adequate theoretical tools. As I have already explained it, the calculations made by the speaker in the process of utterance construction are not the same when he/she opts for THIS or THAT. This shows that linguistic operations are, in fact, like operations of "geometry" where everything is well calculated before it fits its proper place. Therefore, while building utterances, nothing is constructed haphazardly, but everything is carefully selected to form the coherent whole that is the utterance, where grammatical operators do play a fundamental role in semantic interpretation. THIS and THAT form a system showing the two possible ways through which the speaker may represent the world: his/her own perception, which is the outcome of selection from an open paradigm; or a shared perception, which is the outcome of a closed paradigm. But, we would like to draw attention to a very important dimension in utterance building: the speaker may play with these fundamental properties of THIS and THAT to his/her own advantage; for instance, he/she may present a view as presupposed and accepted by the addressee while it is not the case. In such contexts, the addressee can refute that piece of information which ties him/her to a stand he/she does not share. Consider the following examples:
21) "'Whatever you may say you are worried about something,' the old man said. 'It's that damned douche. Drip, drip, drip. Why don't you have it mended?'

'What harm does it do? It's soothing. It sings me to sleep.'" (G. Greene: The Honorary Consul, p.22)

22) "'Ah, there you are, have you caught that thug Wolff?' 'What? What did you say? Wolff a thug! If ever I hear you say one disrespectful thing about that hero, I'll throw you into space to join him.'" (Tintin: Explorers of the Moon)

23) "'What are you going to do with the dynamite?' 'Blow a bridge.' 'What bridge?' 'That is my business.' 'If it is in this territory, it is my business.' 'This is my business.'" (E. Hemingway: For Whom the Bell Tolls, p.14)

These examples show that the addressee does not share the same view as the speaker; therefore, he does not want to be tied up to what the speaker takes for granted. This is why in example (21), the addressee takes distance from the view of the speaker, but in a pleasant way: "What harm does it do? It's soothing. It sings me to sleep." On the contrary, in example (22), the addressee refutes strongly the view that aims to impose the perception of "Wolff as a thug" as an established fact, and replaces it by what he thinks it to be the unarguable quality of Wolff, that is being a hero (THAT HERO). And in example (23), the speaker thinks that he can rely on the complicity of the addressee as the latter knows that he is in charge of conducting operations and implementing war strategies, hence his use of THAT: "THAT is my business." But when he has seen that the addressee is not on the same lines with him, he has replaced 
THAT by THIS in order to use the assertive value of THIS and to show that he sticks to his stand and does not take into consideration the comments of the addressee. We notice here that the same speaker used two different communication strategies according to the message he wanted to transmit, taking into account the progression of discourse. THIS is often used when the speaker wants to dissociate himself from what has been said before or to highlight his position, as the following examples show:

24) "(..) many of the theories we come up with are bogus. They are based on the assumption that voters make cold, rational decisions about who to vote for and can tell us why they decided as they did. This is false.

In reality, we voters -all of us- make emotional, intuitive decisions about who we prefer, and then come up with posthoc rationalizations to explain the choiceswe already made beneath conscious awareness." (International Herald Tribune, January 18, 2008)

25) "NEWSNIGHT - THURSDAY 7 FEBRUARY 22:30 GMT - BBC TWO Hello viewers,

SHARIA LAW IN THE UK? Is this what we really want? The Archbishop of Canterbury - leader of the Church of England - thinks it is unavoidable, and desirable. He told The World at One on BBC Radio 4, "There's a place for finding what would be a constructive accommodation with some aspects of Muslim law, as we already do with some other aspects of religious law." He specified marital disputes and financial disputes and not the "inhumanity" that has sometimes been associated with the practice of the law in some Islamic states.

But is this really the way to achieve "social cohesion" and has he consulted, in particular, British Muslim women for their views on this?

Tonight Newsnight discusses how Sharia would work given equal status to English and Scottish Law, and if Sharia is a legal system you can "pick and choose."

26) "According to this report [the October 2004 report about internal security in France], the cognitive, educational and social development of children that are not forced to speak French at home would be compromised, as they would inevitably have language disorders, leading to behavioural disorders, later resulting in delinquency!

This absurd position reflects a flagrant ignorance of language development and of the role of the mother tongue in the psychic, cognitive and cultural construction of an individual. How for a moment could one imagine that a mother might speak a language that she did not master well to her child?" (Ranka Bijeljac-Babić: "Languages and immigration: bilingualism is an asset" in The UNESCO Courier, N.1, 2008.)

In example (24), the journalist uses THIS to refute what many theories say about how voters think: THIS IS FALSE. This stand of the writer explains his recourse to THIS. If the journalist agreed fully with the previous content and used the word TRUE instead of FALSE, then THAT would have been used instead of THIS: THAT IS TRUE (no comments). But if he agreed partially with the previous content because he had some comments or amendments, then he would use THIS with TRUE, but followed by an operator expressing contrast: THIS IS TRUE, BUT.... The prerogatives of discursive cohesion are to be highlighted in this regard as discursive cohesion is behind these three different possibilities. In fact, the internal organization of language would not allow operations that contradict each other within the same 
utterance, such as THIS which distances the speaker from what has been said before in this example and TRUE which makes him endorse the same piece of information. This also shows that discursive memory operates differently with THIS and THAT. As I have already explained it while analyzing these two operators, when reference is made to the previous context using THIS, choice remains open. But when THAT is used to refer to what has been said before, the speaker endorses what has been stated in its entirety and refers to that item on its own: the choice is closed. This shows that the various operations involved in the building of discourse work harmoniously as a whole to give the final product, which is the utterance. It also confirms what I stated earlier that no operation is made at random in the processing of utterances, hence the importance of exploring grammar in context. In fact, if these operations are invisible, it is the task of linguists to depict and explain them, that is, to render them visible. The explanatory power of the Metaoperational Grammar is to be highlighted in this regard as it makes almost tangible what is still considered as part of the "intricacies of English usage" (S. Levinson, 1983: 81):

Fillmore (1971b: 240) hopes that a theory of discourse deixis will resolve the well-known paradoxes associated with sentences like (92):

[This sentence is not true.] (if it's false, it's true; and if it's true, it's false). (ibid, p.86)

Note that the sentence (92) referred to in this quotation is similar to example (24) with the exception that the latter is given in context, which makes explicit the opposition between the two views in question: "This is not true/false." In fact, THIS is used to show the contrast between the two views: what is "false" for the speaker is "true" for the addressee (or other referents in the context) and vice-versa. Examples (25) and (26) exhibit the same mechanism at work. In both cases the speaker uses THIS to dissociate himself from the previous content. In example (25), the program Newsnight on BBC Two was announced to be devoted that night to the discussion of the proposal by the Archbishop of Canterbury concerning the adoption of some aspects of the Sharia law in the United Kingdom. Call was made for reactions to this story. Using THIS, the journalist clearly distances himself and questions the validity of the Archbishop's comments, leaving the floor open to comments from the audience. And in example (26), the author rejects the idea advocated in the report about internal security in France, using THIS to refer to it as incongruous: THIS ABSURD POSITION. He strongly asserts his position, providing solid arguments.

Sometimes the speaker may refer to something already known by the audience, but if he/she wants to highlight the contrastive aspect of an issue, he/she will use THIS. See in the following example, how George W. Bush used THIS to emphasize his reference to the Arab region as a part of the world, contrasted with other geographical parts in various domains:

27) "Throughout the sweep of history, the lands that the Arab people call home have played a pivotal role in world affairs. These lands sit at the juncture of the three great continents Europe, Asia and Africa. These lands have given birth to three of the world's major religions. These lands have seen the rise and fall of great civilizations. And these lands are once again playing a central role in the human story. (...)

For decades, the people of this region saw their desire for liberty and justice denied at home and dismissed abroad in the name of stability. (...) As freedom and justice advance in this part of the world, 
elections are important, but they're only a start. (...) Across this region, you have an abundance of human capital. (...) In the last few years, the nations of this region have made some great progress. (...) Unfortunately, amid some steps forward in this region we've also seen some setbacks." (President Bush Discusses Importance of Freedom in the Middle East, Abu Dhabi, United Arab Emirates, January 13, 2008)

These examples show the central role of the speaker who uses language patterns matching what he/she intends to communicate, and how grammatical operators play a fundamental role as communication strategies used to build up the intended message. Of course, when what is structured through THIS is fully taken into consideration, or when the speaker and the addressee refer to exactly the same thing, THAT is used to show that in the chronology of abstract operations, THAT is second to THIS, as the latter opens the choice and the former closes it:

28) "'They tell you blow bridges very well. (...) 'You really blow them?' 'Sometimes.'

'You better not have any 'sometimes' on this bridge. No, let us not talk about this bridge. You understand enough now about that bridge.'" (E. Hemingway: For Whom the Bell Tolls, p.11)

29) "He reached into the pannier and picked four grenades. (...) 'Where did these come from?' he asked Eladio.

'Those?

Those are from the Republic.'" (ibid, p.360)

I will close this analysis with this highly illuminating example from Richard II by Shakespeare (Act II, Scene 1), where Gaunt in his tirade uses THIS seventeen (17) times to present how he sees England before using THAT to take back all the descriptions conveyed through the seventeen uses of THIS:

30) "This royal throne of Kings, this scept' red isle,

This earth of majesty, this seat of Mars,

This other Eden, demi-paradise;

This fortress built by nature for herself

Against infection and the hand of war;

This happy breed of men, this little world,

This precious stone set in the silver sea,

Which serves it in the office of a wall,

Or as a moat defensive to a house,

Against the envy of less happier lands;

This blessed plot, this earth, this realm,

This England,

This nurse, this teeming womb of royal kings, (...)

This land of such dear souls, this dear, dear land, (...)

That England, that was wont to conquer others...."

\section{CONCLUSIONS}

This study shows the big difference between descriptive approaches and explanatory approaches. Metaoperational Grammar has enabled me to depict and illustrate how the micro-system THIS/THAT works. It has also shown the important part played by grammatical operators in building semantic interpretation. This is why I have targeted as main objective of this 
study to make visible these invisible operations that take place in the processing of utterances and that determine meaning. In fact, if native speakers can draw unconsciously on these mechanisms to build up their utterances, it is the task of linguists to identify these operations and explain them in order to make conscious this unconscious cognition. This is a prerequisite for gaining proficiency in English as a foreign language, because learners should have a conscious knowledge of how language works in order to master it. One of the big handicaps to this is the direct assignment of meaning to grammatical operators by simply attaching to them meanings pertaining to the real world. This is why descriptive approaches do not help learners to become autonomous, as they do not endow them with the necessary theoretical tools to make the proper choice of the appropriate operator according to the context and the intention of communication. This study has shown that the Metaoperational linguistic framework opens new horizons in the teaching/learning of languages. And since languages are systematic, the micro-system THIS/THAT analysed as revolving around the distinction open paradigm/closed paradigm gives insights into how the English language is organized. This two-dimensional abstract mechanism underlies all the other microsystems of English, which means that once you have understood how one micro-system works, the whole grammar of the English language becomes intelligible.

\section{REFERENCES}

Adamczewski, Henri. Grammaire linguistique de l'anglais. Paris: A. Colin, 1982.

Adamczewski, Henri. Caroline grammairienne en herbe. Ou comment les enfants inventent leur langue maternelle. Paris: Presses de la Sorbonne Nouvelle, 1995.

Adamczewski, Henri \& Jean-Pierre Gabilan. Déchiffrer la grammaire anglaise. Paris: Didier, 1996.

Adamczewski, Henri. Genèse et développement d'une théorie linguistique. Collection Grammatica, France: La Tilv, 1996.

Adamczewski, Henri. Clefs pour Babel ou la Passion des Langues. France: Editions EMA, 1999.

Adamczewski, Henri. The Secret Architecture of English Grammar. France: Editions EMA, 2002.

Brown, Gillian. Speakers, Listeners and Communication: Explorations in Discourse Analysis. Cambridge: Cambridge University Press, 1995.

Chouit, Drissia. L'anaphorisation: de la pronominalisation à l'ellipse. Approche métaopérationnelle.

Analyse contrastive trilingue (anglais, français, arabe) et problèmes de traduction. Doctoral Dissertation, Sorbonne Nouvelle University (Paris 3), 1994.

Chouit, Drissia. "Deixis in Arabic", paper presented at the International Conference on Arabic Linguistics, American University in Cairo, Egypt, December 20-22, 1994.

Chouit, Drissia. "Analyse critique de l'assignation directe du sens dans les approches linguistiques contemporaines". In Langage, Langues et Linguistique N.2, 1995: 25-41.

Chouit, Drissia. "Intertwining Linguistic Approach and Translation: a New Approach to Translation", paper presented at the Thirteenth International Conference on Language, Linguistics, Literature and Translation, Yarmouk University, Jordan, April 1-4, 1996. 
Chouit, Drissia. Une nouvelle approche du micro-système THIS/THAT en anglais contemporain. Collection Grammatica, France: La Tilv, 1997.

Chouit, Drissia. "Assertion/NonAssertion: Reflet de la systématicité et de la cohérence des langues". In Al Misbahia V.7, 2008: 136-160.

Chouit, Drissia \& Abdelhamid Nfissi. Understanding Grammar in Context: A Step-by-Step Guide. Fez: Info-Print, 2018.

Dubos, Ulrika. L'explication grammaticale $d u$ thème anglais. Paris: Nathan, 1990.

Fillmore, Charles. J. "Towards a Theory of Deixis". In The PCCLLU Papers (Department of Linguistics, University of Hawaii), 3.4, 1971:219-41.

Gabilan, Jean-Pierre. Les suites V1/V2 en anglais: V1 Ø V2, V1 TO V2, V1 V2ING. Collection Grammatica, France: La Tilv, 1998.

Halliday, M.A.K. \& Ruqaiya Hasan. Cohesion in English, Great Britain: Longman, 1976.

Hawkins, Eric. Awareness of Language: An Introduction. Cambridge University Press, 1984.

Joly, André \& Dairine O'Kelly. Grammaire systématique de l'anglais. France: Nathan,1990.

Levinson, Stephen C. Pragmatics. Cambridge: Cambridge University Press, 1983.

Lyons, John. Semantics. Vol.2, Cambridge: Cambridge University Press, 1977.

Nfissi,

Abdelhamid. Approche métaopérationnelle de la cohésion discursive. Les connecteurs interphrastiques en anglais, en arabe et en français. Etude contrastive et problèmes de traduction. Lille, France: Presses
Universitaires du Septentrion, 1996.

Nfissi, Abdelhamid. "BUT, THOUGH et ALTHOUGH et l'expression de la discordance: étude métaopérationnelle". In Linguistische Arbeiten 351, C. Muller Editor, Turbingen: Niemeyer, 1996: 227-232.

Quirk, Randolph \& Sidney Greenbaum. $A$ University Grammar of English. Hong Kong: Longman, 1973.

Zandvoort, R.W. A Handbook of English Grammar. 2nd ed. Great Britain: Western Printing Services LTD, 1962. 